ARTICLE

\title{
Dual clumped isotope thermometry resolves kinetic biases in carbonate formation temperatures
}

\author{
David Bajnai (1) 1,9凶, Weifu Guo (1) 2 , Christoph Spötl (10 ${ }^{3}$, Tyler B. Coplen (1) 4, Katharina Methner (1) ${ }^{5}$, \\ Niklas Löffler (10 1,6, Emilija Krsnik (10 1,6, Eberhard Gischler', Maximilian Hansen (1) ${ }^{6}$, Daniela Henkel ${ }^{7}$, \\ Gregory D. Price (iD) ${ }^{8}$, Jacek Raddatz (1) ${ }^{1}$, Denis Scholz (i) ${ }^{6} \&$ Jens Fiebig (iD ${ }^{1 \times}$
}

Surface temperature is a fundamental parameter of Earth's climate. Its evolution through time is commonly reconstructed using the oxygen isotope and the clumped isotope compositions of carbonate archives. However, reaction kinetics involved in the precipitation of carbonates can introduce inaccuracies in the derived temperatures. Here, we show that dual clumped isotope analyses, i.e., simultaneous $\Delta_{47}$ and $\Delta_{48}$ measurements on the single carbonate phase, can identify the origin and quantify the extent of these kinetic biases. Our results verify theoretical predictions and evidence that the isotopic disequilibrium commonly observed in speleothems and scleractinian coral skeletons is inherited from the dissolved inorganic carbon pool of their parent solutions. Further, we show that dual clumped isotope thermometry can achieve reliable palaeotemperature reconstructions, devoid of kinetic bias. Analysis of a belemnite rostrum implies that it precipitated near isotopic equilibrium and confirms the warmer-than-present temperatures during the Early Cretaceous at southern high latitudes.

\footnotetext{
${ }^{1}$ Institute of Geosciences, Goethe University Frankfurt, Altenhöferallee 1, Frankfurt am Main 60438, Germany. ${ }^{2}$ Department of Geology and Geophysics, Woods Hole Oceanographic Institution, 266 Woods Hole Road, Woods Hole, MA 02543, USA. ${ }^{3}$ Institute of Geology, University of Innsbruck, Innrain 52, Innsbruck 6020, Austria. ${ }^{4}$ US Geological Survey, 12201 Sunrise Valley Drive, Reston, VA 20192, USA. ${ }^{5}$ Senckenberg Biodiversity and Climate Research Centre (SBiK-F), Senckenberganlage 25, Frankfurt am Main 60325, Germany. ${ }^{6}$ Institute of Geosciences, Johannes Gutenberg University Mainz, JohannJoachim-Becher-Weg 21, Mainz 55128, Germany. ${ }^{7}$ GEOMAR Helmholtz Centre for Ocean Research, Wischhofstr. 1-3, Kiel 24148, Germany. ${ }^{8}$ School of Geography, Earth and Environmental Sciences, University of Plymouth, Drake Circus, Plymouth PL4 8AA, UK. ${ }^{9}$ Present address: Institute of Geology and Mineralogy, University of Cologne, Zülpicher Str. 49b, Cologne 50674, Germany. ${ }^{凶}$ email: david.bajnai@em.uni-frankfurt.de; jens.fiebig@em.uni-frankfurt.de
} 
P alaeotemperature reconstructions are fundamental for understanding climatic changes in Earth's past. For a long time, the oxygen isotope composition $\left(\delta^{18} \mathrm{O}\right)$ of carbonate remains of marine calcifiers and terrestrial carbonates has served as one of the most widely used palaeotemperature proxies ${ }^{1-3}$. However, to reconstruct carbonate growth temperatures using the oxygen isotope thermometer, the oxygen isotope composition of the (palaeo)fluid from which the carbonate mineral crystallised must be known. Uncertainties in estimating the oxygen isotope composition of these (palaeo)fluids, e.g., ancient seawater or meteoric precipitation, make $\delta^{18} \mathrm{O}$-based temperature reconstructions ambiguous. The carbonate clumped isotope $\left(\Delta_{47}\right)$ thermometer overcomes this problem by examining the clumping of ${ }^{13} \mathrm{C}$ and ${ }^{18} \mathrm{O}$ isotopes within a single carbonate phase ${ }^{4}$ and eliminates the need to know the isotopic composition of the water from which carbonates precipitated. Under thermodynamic equilibrium, the clumped isotope composition of a carbonate only depends on its crystallisation temperature.

However, in addition to temperature and fluid $\delta^{18} \mathrm{O}$, kinetic effects occurring during carbonate (bio)mineralisation can influence the isotopic composition of the carbonates. Departures from oxygen isotope and clumped isotope equilibrium due to kinetic effects pose considerable challenges in obtaining accurate palaeotemperature estimates. Such kinetic departures are present in most Earth-surface carbonates ${ }^{5}$, most notably speleothems ${ }^{2,6-9}$, brachiopod shells ${ }^{10-13}$, and coral skeletons ${ }^{14-20}$. If unaccounted for, these kinetic biases could lead to significant over- or underestimation of the carbonate formation temperatures $6,7,12,16,18,21$. Despite numerous efforts, it remains difficult to identify and correct for these kinetic effects, especially in extinct calcifiers without modern analogues ${ }^{22-24}$.

The $\Delta_{48}$ value is a measure of the excess abundance of the ${ }^{18} \mathrm{O}-$ ${ }^{12} \mathrm{C}-{ }^{18} \mathrm{O}$ isotopologue in a given pool of $\mathrm{CO}_{2}$ molecules relative to the stochastic distribution ${ }^{25}$. Theoretical studies suggest that simultaneous measurements of $\Delta_{48}$ and $\Delta_{47}$ in $\mathrm{CO}_{2}$ evolved from phosphoric acid digestion of carbonates, referred to here as dual clumped isotope thermometry, can identify kinetic effects involved in carbonate formation ${ }^{26,27}$. Moreover, this method holds the potential to correct for kinetic biases and derive accurate temperature estimates ${ }^{26,27}$. Precise determination of carbonate $\Delta_{48}$ values has not been possible until recent advances in mass spectrometry, due to the very low abundance of ${ }^{18} \mathrm{O}-{ }^{12} \mathrm{C}-$ ${ }^{18} \mathrm{O}$, the main isotopologue contributing to the $\Delta_{48}$ signal in carbonate minerals ${ }^{25}$.

Here we report simultaneous high precision $\Delta_{47}$ and $\Delta_{48}$ measurements on representative carbonate samples of different origins and demonstrate the potential of dual clumped isotope thermometry in quantitative palaeotemperature reconstruction by comparing these experimental observations with independent theoretical predictions.

\section{Results}

The temperature dependence of equilibrium $\Delta_{47}$ and $\Delta_{48}$ values. Before examining the potential kinetic isotope effects in our carbonate samples, we constrained the equilibrium $\Delta_{47}$ vs $\Delta_{48}$ relationship for carbonates by integrating theoretical estimations with experimental measurements (Fig. 1). First, we derived empirical equilibrium $\Delta_{47}$ (CDES90) vs temperature and $\Delta_{48 \text { (CDES90) }}$ vs temperature relationships by combining the theoretically estimated equilibrium temperature dependence of carbonate $\Delta_{63}$ and $\Delta_{64}$ values ${ }^{28}$ with our experimentally determined acid fractionation factors $(0.194 \%$ and $0.138 \%$, respectively, see "Methods"). We chose to use the theoretical calcite calibration for both calcite and aragonite minerals, as no systemic difference in equilibrium $\Delta_{47}$ values between the two has been observed in the
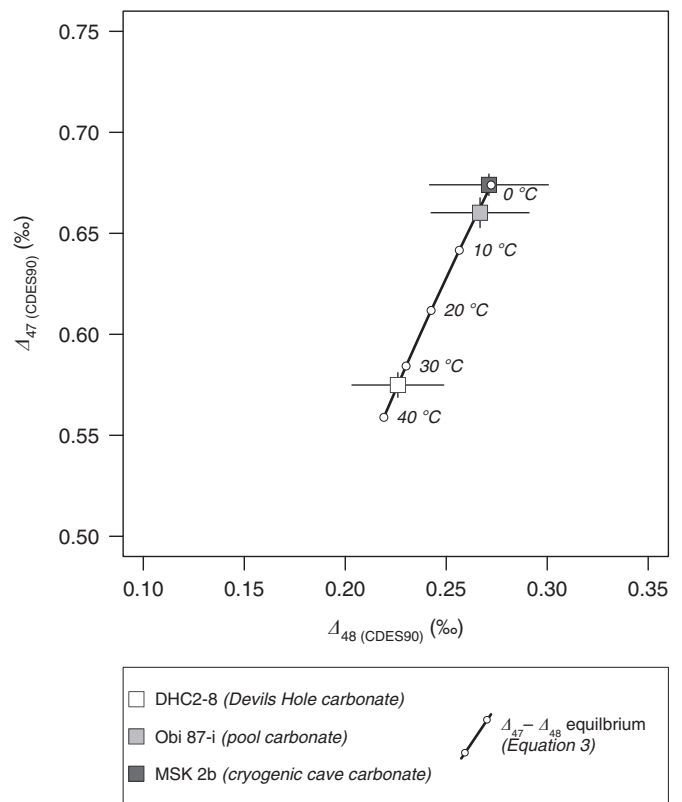

Fig. 1 The equilibrium relationship between carbonate $\Delta_{47}$ (CDES90) and $\Delta_{\mathbf{4 8}}$ (CDES90) values. The estimated equilibrium relationship is obtained by combining the empirical $\Delta_{47}$ (CDES90) vs temperature and $\Delta_{48}$ (CDES90) VS temperature relationships after anchoring each to the measured isotopic composition of the Devils Hole carbonate (Eqs. (1-3); see text for details). The fact that the mean $\Delta_{47}$ (CDES90) and $\Delta_{48}$ (CDES90) values of the pool carbonate and the cryogenic carbonate samples, both of which are thought to form very close to isotopic equilibrium (see "Methods" and Supplementary Fig. 1), fall within $\pm 0.001 \%$ of the expected equilibrium values confirm the robustness of our equilibrium line.

majority of studies ${ }^{29}$. Secondly, we analysed the clumped isotope composition of a vein calcite from Devils Hole (DHC2-8) and used it to anchor our empirically derived equilibrium $\Delta_{47}$ (CDES90) vs temperature and $\Delta_{48}$ (CDES90) vs temperature relationships. The Devils Hole carbonate is believed to have precipitated extremely slowly $\left(0.1-0.8 \mu \mathrm{m}\right.$ year $\left.^{-1}\right)$ under stable environmental conditions at $33.7( \pm 0.8)^{\circ} \mathrm{C}$, and thus its isotopic composition has been postulated to represent thermodynamic equilbrium ${ }^{5,30-32}$. Specifically, we calculated the differences between the $\Delta_{47}$ (CDES90) and $\Delta_{48}$ (CDES90) values of DHC2-8 and the corresponding values predicted by our empirical relationships at $33.7^{\circ} \mathrm{C}$. We then added these differences $\left(0.010 \%\right.$ for $\Delta_{47}$ (CDES90) and $-0.021 \%$ for $\left.\Delta_{48}(\mathrm{CDES} 90)\right)$ to the empirical relationships, leading to the final equilibrium relationships $\left(0-40^{\circ} \mathrm{C}\right)$ :

$$
\begin{aligned}
\Delta_{47(\mathrm{CDES} 90)}= & 0.3642-2.914 \times 10^{2} / T+1.800 \times 10^{5} / T^{2} \\
& -2.657 \times 10^{7} / T^{3}+1.493 \times 10^{9} / T^{4}, \\
\Delta_{48(\mathrm{CDES} 90)}= & 0.1742-5.897 \times 10 / T+1.252 \times 10^{4} / T^{2} \\
& +5.039 \times 10^{6} / T^{3}-5.631 \times 10^{8} / T^{4},
\end{aligned}
$$

where $T$ is in K. Lastly, the combination of Eqs. (1) and (2) leads to our estimated equilibrium $\Delta_{47}$ (CDES90) vs $\Delta_{48}$ (CDES90) relationship for carbonates (Fig. 1):

$$
\begin{aligned}
\Delta_{47(\mathrm{CDES} 90)}= & -0.4771+9.102 \times \Delta_{48(\mathrm{CDES} 90)}-31.709 \times \Delta_{48(\mathrm{CDES} 90)}^{2} \\
& +65.561 \times \Delta_{48(\mathrm{CDES} 90)}^{3}-54.560 \times \Delta_{48(\mathrm{CDES} 90)}^{4} .
\end{aligned}
$$

To check whether Eqs. (1-3) indeed represent thermodynamic equilibrium, especially at temperatures below $33.7^{\circ} \mathrm{C}$, we 
Table 1 Long-term $\Delta_{47}$ (CDES90) and $\Delta_{48}$ (CDES90) values of carbonate reference materials.

\begin{tabular}{|c|c|c|c|c|c|}
\hline Standard & Replicates & $\Delta_{47 \text { (CDES90) }}(\% o)$ & 2 SE (1 SD) & $\Delta_{48 \text { (CDES } 90)}(\% o)$ & 2 SE (1 SD) \\
\hline ETH 1 & 78 & 0.212 & $0.002(0.010)$ & 0.142 & $0.008(0.036)$ \\
\hline ETH 2 & 71 & 0.212 & $0.003(0.011)$ & 0.138 & $0.007(0.029)$ \\
\hline ETH 3 & 74 & 0.615 & $0.002(0.010)$ & 0.299 & $0.010(0.042)$ \\
\hline
\end{tabular}

This table considers data measured during the April-August 2019 measurement period combined with those reported in Fiebig et al. ${ }^{25}$. All replicate analyses from the April-August 2019 measurement period are presented in Supplementary Data 1. The average $\Delta_{47}$ (CDES90) and $\Delta_{48}$ (CDES90) values for the total number (149) of ETH 1 and ETH 2 replicates are $0.212( \pm 0.002) \%$ and $0.140( \pm 0.005) \%$, respectively. SE, standard error; $S D$, standard deviation.

Table 2 Clumped isotope composition ( $\Delta_{47}$ (CDES90) and $\Delta_{48}$ (CDES90) $)$ of the samples.

\begin{tabular}{|c|c|c|c|c|c|}
\hline Sample (type) & Replicates & $\Delta_{47}($ CDES 90$)(\%)$ & $2 \mathrm{SE}$ & $\Delta_{48}$ (CDES90) $(\%)$ & $2 \mathrm{SE}$ \\
\hline$\overline{\mathrm{DHC} 2-8 \text { (vein calcite) }}$ & 5 & 0.575 & 0.006 & 0.226 & 0.023 \\
\hline Obi 87-i (pool carbonate) & 7 & 0.660 & 0.007 & 0.267 & 0.024 \\
\hline MSK 2b (cryogenic cave carbonate) & 8 & 0.674 & 0.005 & 0.271 & 0.029 \\
\hline MHD1 (synthetic speleothem) & 6 & 0.547 & 0.008 & 0.254 & 0.027 \\
\hline SPA121-02 (stalagmite) & 6 & 0.644 & 0.009 & 0.290 & 0.025 \\
\hline PC1_2005 (warm-water coral) & 10 & 0.626 & 0.005 & 0.136 & 0.022 \\
\hline JR (cold-water coral) & 10 & 0.719 & 0.005 & 0.189 & 0.030 \\
\hline Mv143-b (brachiopod) & 9 & 0.675 & 0.004 & 0.250 & 0.015 \\
\hline 66-4.65 (belemnite) & 9 & 0.610 & 0.005 & 0.251 & 0.021 \\
\hline
\end{tabular}

This table considers data measured during the April-August 2019, September-December 2019, and January-March 2020 measurement periods. All replicate analyses are presented in Supplementary Data 2-4. The $\delta^{18} \mathrm{O}$ and $\delta^{13} \mathrm{C}$ values of the samples are reported in Supplementary Table 1.

analysed two additional carbonate samples which are thought to have precipitated slowly from their parent solutions and thus may exhibit equilibrium $\Delta_{47}$ and $\Delta_{48}$ signatures: a cave pool carbonate (Obi 87-i) and a cryogenic cave carbonate (MSK 2b), formed at 4 $( \pm 1.5){ }^{\circ} \mathrm{C}$ and $0{ }^{\circ} \mathrm{C}$, respectively (see "Methods"). In particular, the $\delta^{13} \mathrm{C}$ and $\delta^{18} \mathrm{O}$ values of the cryogenic carbonate sample suggest crystallisation over the final stage of the freezing process during which isotopic equilibrium is closely approached ${ }^{33,34}$ (Supplementary Table 1 and Supplementary Fig. 1). The $\Delta_{47}$ (CDES90) and $\Delta_{48}$ (CDES90) values of both the pool carbonate and the cryogenic carbonate fall within $\pm 0.001 \%$ of the equilibrium values calculated using Eqs. (1) and (2) (Fig. 1), strongly supporting the robustness of our equilibrium $\Delta_{47}$ and $\Delta_{48}$ relationships. Furthermore, our estimated temperature dependence of carbonate $\Delta_{47}$ (CDES90) (Eq. (1)) is indistinguishable (within $\pm 0.010 \%$ ) from the $\Delta_{47}$ vs temperature relationship derived from laboratory-synthesised carbonates (Supplementary Fig. 2) ${ }^{29}$.

Carbonates formed in kinetic environments. The clumped isotope composition and the corresponding uncertainties of the carbonate standards and samples analysed in this study are listed in Tables 1 and 2, respectively. In addition to the carbonates that have formed in or close to thermodynamic equilibrium (i.e. the Devils Hole carbonate, the cave pool carbonate, and the cave cryogenic carbonate; see above), we analysed representative carbonates from a variety of kinetic environments (see "Methods"), including a synthetic speleothem, a natural stalagmite (Spannagel Cave, Austria), a warm-water coral (Porites lutea), a cold-water coral (Desmophyllum pertusum), a modern brachiopod (Magellania venosa), and a fossil belemnite (Belemnopsis sp.).

The mean clumped isotope values of our analysed samples range from $0.547 \%$ to $0.719 \%$ for $\Delta_{47}$ (CDES90) values, and from $0.136 \%$ to $0.290 \%$ o for $\Delta_{48}$ (CDES90) values (Fig. 2a, Table 2, Supplementary Fig. 2). Except for the belemnite sample, which plots within 2 SE ( $95 \%$ confidence interval ${ }^{35}$ ) of the equilibrium $\Delta_{47}$ (CDES90) vs $\Delta_{48}$ (CDES90) line (Eq. (3)), all the other investigated carbonate samples show significant offsets from the expected clumped isotope equilibrium (Fig. 2, Supplementary Fig. 2). Both the synthetic speleothem and the stalagmite plot below the $\Delta_{47}$ (CDES90) vs $\Delta_{48}$ (CDES90) equilibrium line, with offsets of $-0.036 \%$ and $-0.030 \%$ in the $\Delta_{47}$ (CDES90) values and $+0.024 \% 0$ and $+0.018 \%$ in the $\Delta_{48}$ (CDES90) values, respectively. In contrast, the two modern corals and the brachiopod plot above the equilibrium line, with offsets ranging from $+0.038 \%$ to $+0.069 \%$ in $\Delta_{47}$ (CDES90) and from $-0.004 \%$ o to $-0.095 \%$ in $\Delta_{48}$ (CDES90).

\section{Discussion}

If clumped isotope equilibrium was attained in all samples, their $\Delta_{47}$ (CDES90) and $\Delta_{48}$ (CDES90) values should correlate, due to the exclusive temperature dependence of clumped isotope equilibrium. The fact that the $\Delta_{47}$ (CDES90) and $\Delta_{48}$ (CDES90) values of our investigated samples do not follow such a simple trend provides the most substantial evidence so far that most of these carbonates did not form under isotopic equilibrium (Fig. 2a, Supplementary Fig. 2). Kinetic departures from isotopic equilibrium in the carbonate-water system generally arise from two processes: the slow conversion between dissolved carbon dioxide $\left(\mathrm{CO}_{2}(\mathrm{aq})\right.$ ) and bicarbonate $\left(\mathrm{HCO}_{3}{ }^{-}\right)$through (de)hydration/(de) hydroxylation reactions (Eqs. (4) and (5), respectively) ${ }^{36}$ and the incorporation of dissolved inorganic carbon species (DIC) into the carbonate crystal lattice ${ }^{37,38}$.

$$
\begin{gathered}
\mathrm{CO}_{2(\mathrm{aq})}+\mathrm{H}_{2} \mathrm{O} \leftrightarrow \mathrm{H}^{+}+\mathrm{HCO}_{3}^{-} \\
\mathrm{CO}_{2(\mathrm{aq})}+\mathrm{OH}^{-} \leftrightarrow \mathrm{HCO}_{3}^{-}
\end{gathered}
$$

While DIC incorporation seems to introduce only negligible departures from clumped isotope equilibrium ${ }^{32,39,40}$, kinetics associated with the (de)hydration/(de)hydroxylation reactions are predicted to introduce large disequilibrium signatures in the $\Delta_{63}$ and $\Delta_{64}$ values of the DIC ${ }^{26,27}$. These disequilibrium $\Delta_{63}$ and $\Delta_{64}$ values of the DIC are expected to be directly transcribed to the $\Delta_{47}$ and $\Delta_{48}$ values of the carbonates when carbonates precipitate quickly from the solution. 

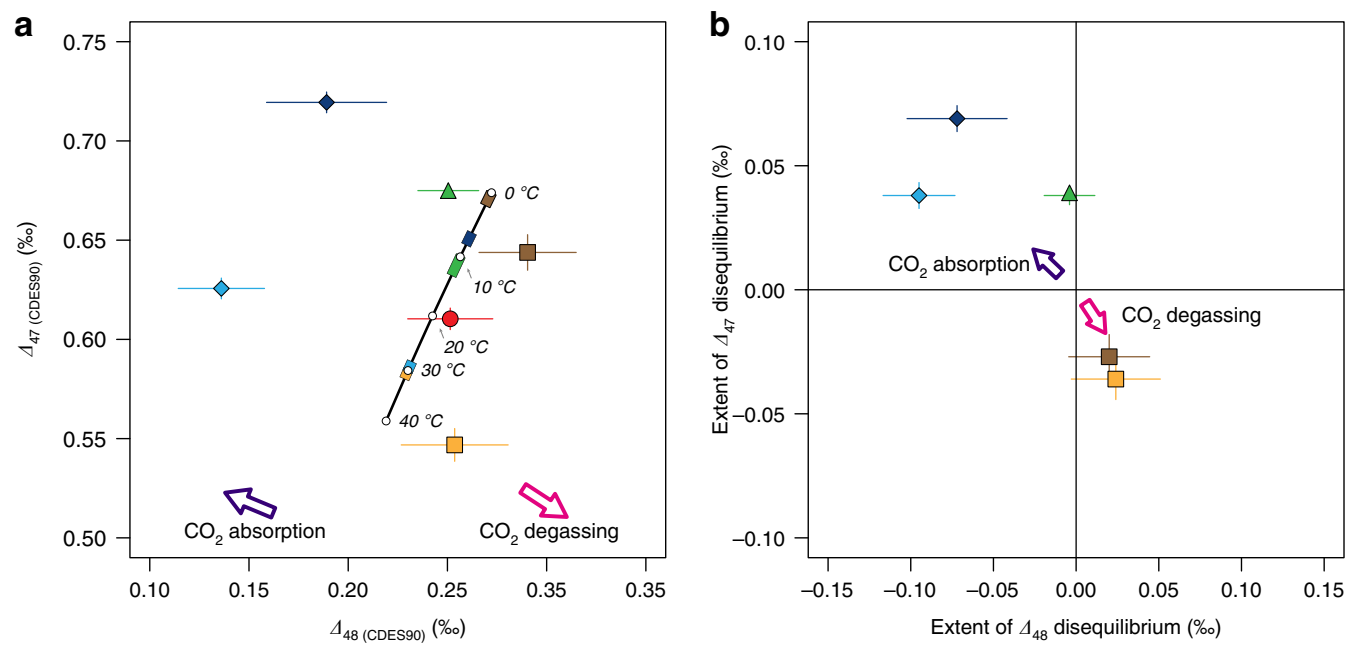

\begin{tabular}{|c|c|}
\hline \multirow{3}{*}{$\begin{array}{l}\square \text { MHD1 (synthetic speleothem) } \\
\square \text { SPA121-02 (stalagmite) }\end{array}$} & $\triangle$ PC1_2005 (warm-water coral \\
\hline & $\diamond \mathrm{JR}$ (cold-water coral) \\
\hline & $\triangle$ Mv143-b (brachiopod) \\
\hline & $66-4.65$ (belemnite) \\
\hline
\end{tabular}

Fig. 2 The nature and extent of kinetic isotope effects in representative carbonates. a The isotopic compositions of the stalagmite, synthetic speleothem, cold-water coral, warm-water coral, and the brachiopod deviate significantly from their respective equilibrium compositions (coloured rectangles on the equilibrium line), while the belemnite is indistinguishable from the equilibrium line. $\mathbf{b}$ The cold- and warm-water corals show positive $\Delta_{47}$ (CDES90) offsets and negative $\Delta_{48}$ (CDES90) offsets from the thermodynamic equilibrium, which are consistent with kinetic effects derived from $\mathrm{CO}_{2}$ absorption (purple arrow). In comparison, the stalagmite and the synthetic speleothem show negative $\Delta_{47}$ (CDES90) offsets and positive $\Delta_{48}$ (CDES90) offsets that are consistent with kinetic effects derived from $\mathrm{CO}_{2}$ degassing (pink arrow). Disequilibrium offsets were calculated relative to the equilibrium $\Delta_{47}$ (CDES90) and $\Delta_{48}$ (CDES90) values expected at the corresponding carbonate growth temperatures (Eqs. (1-3)). All error bars depict 2 standard errors (95\% confidence interval $\left.{ }^{35}\right)$.

Specifically, under open-system conditions, the evolution of the clumped isotope composition of the DIC follows nonlinear trajectories in $\Delta_{47}$ vs $\Delta_{48}$ space $^{26}$. For example, for an aqueous solution starting from isotopic equilibrium, the carbonate clumped isotope compositions will increasingly deviate from equilibrium during $\mathrm{CO}_{2}$ degassing and $\mathrm{CO}_{2}$ absorption, i.e., when dehydration/dehydroxylation reactions dominate over the hydration/hydroxylation reactions, and vice versa (Eqs. 4 and 5). However, as the forward reaction progresses and the product concentration increases, the backward reaction will become more and more significant until the forward and backward reaction rates become identical and the isotopic equilibrium is attained again (Fig. 3a) ${ }^{26,27}$. The exact pattern and extent of these disequilibrium effects during $\mathrm{CO}_{2}$ absorption and $\mathrm{CO}_{2}$ degassing depend on several parameters ${ }^{26,27}$, such as solution temperature, $\mathrm{pH}$, the isotopic compositions of the gaseous $\mathrm{CO}_{2}$ and the solution, and for calcifying organisms, carbonic anhydrase activity that facilitates the interconversion between dissolved carbon dioxide and bicarbonate (Fig. 3a).

Most carbonates in our study exhibit systematic departures from the clumped isotope equilibrium line (Eqs. (1-3)) that are consistent with the model predictions ${ }^{26,27}$, supporting that $\mathrm{CO}_{2}$ absorption and $\mathrm{CO}_{2}$ degassing reactions are the primary drivers for the observed departures from isotopic equilibrium (Fig. 3a). During scleractinian coral biomineralisation, carbon dioxide derived from metabolic respiration is transformed to bicarbonate via hydration/hydroxylation reactions (Eqs. (4) and (5)) in the calcifying fluid and then subsequently to carbonate ion $\left(\mathrm{CO}_{3}{ }^{2-}\right)$ from which the solid carbonate skeleton precipitates ${ }^{14,26}$. In the early stage of $\mathrm{CO}_{2}$ absorption, the $\Delta_{47}$ values of coral skeletons are predicted to show a positive departure from the expected equilibrium values while their $\Delta_{48}$ values show a negative offset (Fig. 3a, Supplementary Data 5). Such a pattern is observed in both the warm-water and cold-water corals in our study (Fig. 2).
Moreover, the observed offsets from the respective equilibrium $\Delta_{47}$ and $\Delta_{48}$ values co-vary and plot close to the model predictions where the $\mathrm{CO}_{2}$ absorption kinetics dominate (Fig. 3a, see "Methods"). Similar to the two scleractinian corals, the isotopic composition of the fast-growing brachiopod (Magellania venosa) plots above the $\Delta_{47}$ vs $\Delta_{48}$ equilibrium line (Fig. 2a), showing a positive offset in $\Delta_{47}$ but only a minimal negative offset in $\Delta_{48}$ (Fig. 2b). The direction of such departures from equilibrium is consistent with the disequilibrium initiated by hydration/hydroxylation reaction ${ }^{26}$, supporting earlier suggestions that hydration and hydroxylation reactions are the dominant causes of the observed clumped isotope disequilibrium in modern brachiopods ${ }^{12}$.

Speleothem precipitation, unlike biomineralisation, is induced by the degassing of $\mathrm{CO}_{2}$ from aqueous solutions. The removal of $\mathrm{CO}_{2}$ from the very thin solution film on the surface of a speleothem, i.e., the transformation of bicarbonate to dissolved carbon dioxide via dehydration/dehydroxylation reactions (backward reactions in Eqs. (4) and (5)), increases the saturation state of calcium carbonate and leads to carbonate precipitation $^{6,27,41,42}$. In the early stages of $\mathrm{CO}_{2}$ degassing, carbonate $\Delta_{47}$ values are expected to show a negative offset and $\Delta_{48}$ values to show a positive offset from equilibrium ${ }^{27}$ (Fig. 3a, Supplementary Data 5). This pattern is observed in the isotopic compositions of both the synthetic speleothem and the stalagmite samples, which plot below the clumped isotope equilibrium line (Fig. 2). Moreover, the $\Delta_{47}$ and $\Delta_{48}$ offsets observed in the synthetic speleothem quantitatively agree with the model prediction that explicitly simulates this carbonate formation ${ }^{27}$ (Fig. 3a, see "Methods").

The agreements between the measured carbonate clumped isotope compositions and our model simulations suggest that dual clumped isotope analysis can be used to identify the dominant reactions involved in carbonate (bio)mineralisation. 

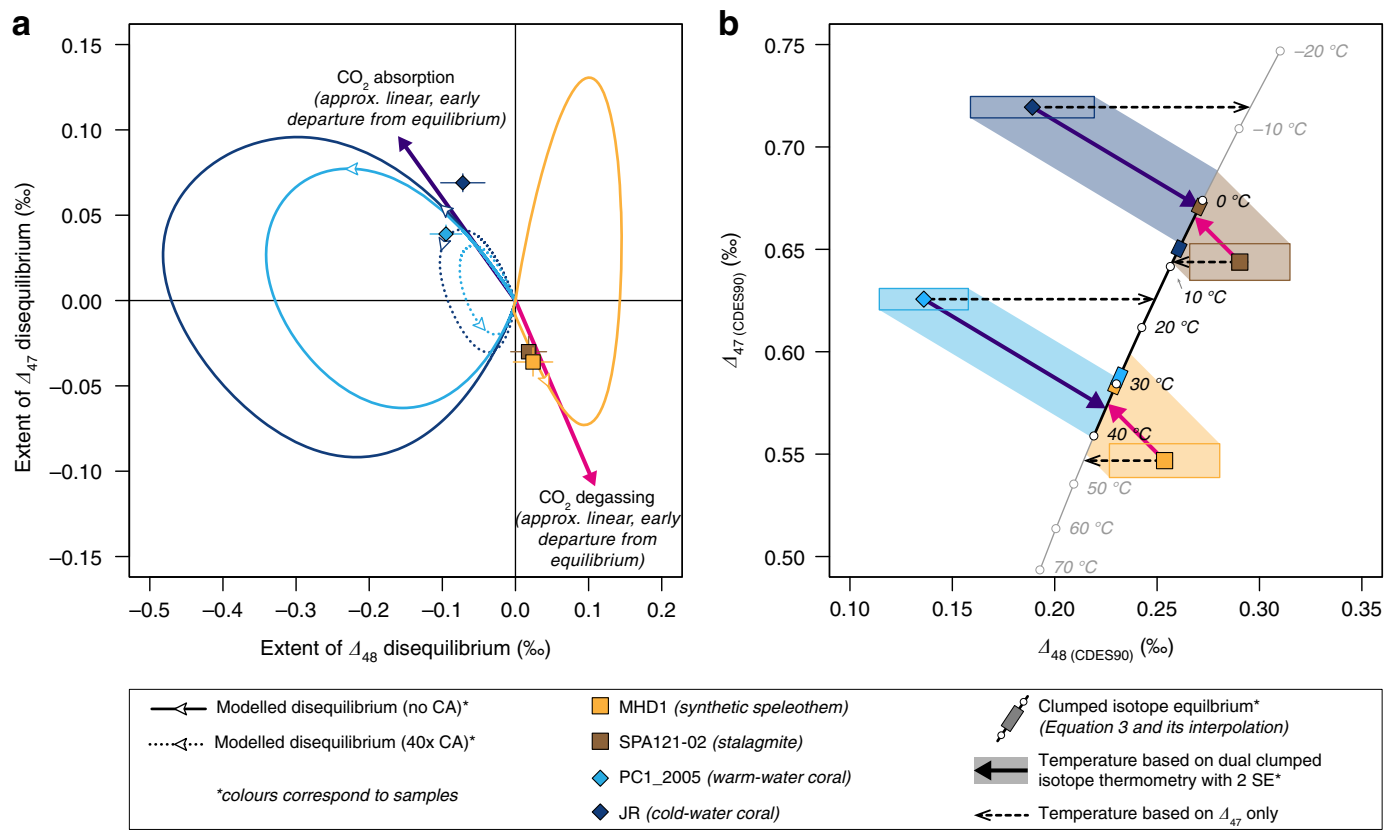

Fig. 3 Agreements between model predictions and measured data allow accurate reconstruction of carbonate formation temperatures despite kinetic bias. a The deviations from clumped isotope $\left(\Delta_{47}\right.$ and $\left.\Delta_{48}\right)$ equilibrium observed in the warm- and cold-water corals and the synthetic speleothem agree with the model-predicted kinetic departures 26,27 . Carbonic anhydrase accelerates oxygen isotope and clumped isotope exchange among different DIC species during $\mathrm{CO}_{2}$ absorption. The white arrows on the model lines depict the temporal evolution of the predicted disequilibrium effects and are positioned to mark $t=500 \mathrm{~s}$ in the $\mathrm{CO}_{2}$ absorption model simulations and $t=170$ s (i.e., when $50 \%$ of carbonate precipitation proceeded) in the speleothem model simulation, respectively (Methods, Supplementary Data 5). Note, that unlike the speleothem model that simulates the exact formation of our synthetic speleothem sample, the $\mathrm{CO}_{2}$ absorption model is a simplification of coral calcification process and thus the timing information in the model has no direct implication on the timescale of coral calcification process. The models predict an almost linear correlation between $\Delta_{47}$ and $\Delta_{48}$ disequilibrium during the early stage of $\mathrm{CO}_{2}$ absorption and $\mathrm{CO}_{2}$ degassing, with slopes of -0.6 and -1.0 , respectively (the purple and the pink arrows; Supplementary Data 5). b Kinetic effects lead to significant underestimation of the coral growth temperature but overestimation of the speleothem formation temperatures based on their $\Delta_{47}$ compositions alone (horizontal, dashed arrows). However, using the model-predicted kinetic slopes, i.e., -0.6 for corals (purple arrows) and -1.0 for speleothems (pink arrows), the isotopic composition of these samples can be projected onto the $\Delta_{47}$ vs $\Delta_{48}$ equilibrium curve to derive more accurate estimates of carbonate formation temperatures 26,27 . Temperatures estimated this way are devoid of kinetic bias and agree within 2 SE with the actual carbonate growth temperatures. All error bars and rectangles depict 2 standard errors ( $95 \%$ confidence interval ${ }^{35}$ ).

Furthermore, when combined with numerical modelling, coupled $\Delta_{47}$ and $\Delta_{48}$ analysis shall allow a more accurate reconstruction of the carbonate formation environment such as temperature, $\mathrm{pH}$, and carbonic anhydrase activity ${ }^{26,27}$. In particular, disequilibrium offsets observed in the two scleractinian corals and the natural and synthetic speleothems fall close to the initial linear segment of the model-predicted departure from isotopic equilibrium, whose slope is relatively insensitive to temperature, $\mathrm{pH}$, and carbonic anhydrase activity ${ }^{26}$ (Fig. 3a). This opens up a unique opportunity to accurately reconstruct carbonate formation temperatures even if the measured $\Delta_{47}$ and $\Delta_{48}$ values were affected by kinetic effects ${ }^{26,27}$. Under the conditions specific to the formation of our samples (see "Methods"), the model predicts approximately linear correlations between disequilibrium $\Delta_{47}$ and $\Delta_{48}$ values in carbonates formed during the early stages of $\mathrm{CO}_{2}$ degassing and $\mathrm{CO}_{2}$ absorption, with slopes of -1.0 and -0.6 , respectively (Fig. 3a, Supplementary Data 5). Projecting the measured carbonate isotope composition to the equilibrium $\Delta_{47}$ and $\Delta_{48}$ line (Eq. (3)) along these predicted linear kinetic trajectories, shall yield their actual formation temperatures, unbiased by kinetic effects 26,27 . Specifically, this leads to temperature estimates of $34( \pm 9)^{\circ} \mathrm{C}, 2( \pm 7){ }^{\circ} \mathrm{C}, 1( \pm 5)^{\circ} \mathrm{C}$, and $34( \pm 6)^{\circ} \mathrm{C}$ for the synthetic speleothem, the stalagmite, the cold-water coral, and the warm-water coral, respectively (Fig. 3b). These temperature estimates are indistinguishable within $2 \mathrm{SE}$ from the actual formation temperatures of these carbonates, i.e., $30.7( \pm 0.3)^{\circ} \mathrm{C}$, $0.0( \pm 2.0){ }^{\circ} \mathrm{C}, 7.2( \pm 1.0)^{\circ} \mathrm{C}$, and $29.3( \pm 1.0)^{\circ} \mathrm{C}$, respectively. In contrast, estimates based on the measured $\Delta_{47}$ data alone would result in inaccurate and unreasonable temperatures (Fig. 3b). For example, for the synthetic speleothem, the observed disequilibrium $\Delta_{47}$ effect of $-0.036 \%$ is similar to that observed in some natural systems ${ }^{43}$, and would yield a temperature that is $10-18^{\circ} \mathrm{C}$ too warm compared to its actual formation temperature. Similarly, $\Delta_{47}$ thermometry would overestimate the formation temperatures of the stalagmite sample by $4-14^{\circ} \mathrm{C}$, while the $\Delta_{47}$-derived temperatures of the warm-water and the cold-water corals would be lower than their actual growth temperatures by $11-17^{\circ} \mathrm{C}$ and $18-22^{\circ} \mathrm{C}$, respectively.

For the modern brachiopod specimen, however, even after correction using a model-predicted kinetic slope of -0.6 for $\mathrm{CO}_{2}$ absorption, one would still underestimate its growth temperature by $4-13^{\circ} \mathrm{C}$. Compared to scleractinian coral calcification, the mechanism of brachiopod calcification is less explored ${ }^{12,13}$. The current model simulations of $\mathrm{CO}_{2}$ absorption were designed based on the mechanism of coral calcification and thus may not have captured the primary sources of isotopic disequilibrium in brachiopods. More studies on specimens of known growth temperatures are required to evaluate the full potential that dual clumped isotope thermometry holds for accurate palaeotemperature reconstructions. However, if it were demonstrated that isotopic compositions of most biogenic carbonates and speleothems follow the early, linear trajectory of departure from equilibrium, accurate palaeotemperature reconstructions would become possible on 
well-preserved samples even if they are affected by kinetic effects.

The dual clumped isotope analysis also makes it possible to evaluate the extent of isotopic disequilibrium in fossil carbonates, even if the carbonate's growth temperature and the isotopic composition of its parent water are not known. This, for the first time, offers the opportunity to investigate if the isotopic composition of extinct calcifiers was affected by kinetic effects. The isotopic composition of the Cretaceous belemnite sample falls within $2 \mathrm{SE}$ of the $\Delta_{47}$ vs $\Delta_{48}$ equilibrium line (Fig. 2a), suggesting that it precipitated indistinguishable from thermodynamic equilibrium at a temperature of $20.5( \pm 1.9)^{\circ} \mathrm{C}$. This temperature estimate supports southern high-latitude warmth during the Early Cretaceous $^{44,45}$.

More generally, our finding that the belemnite did but the brachiopod did not form in isotopic equilibrium has significant implications for the palaeotemperature estimates derived from the oxygen isotope compositions of these two archives. Multiple studies have reported colder $\delta^{18} \mathrm{O}$-derived belemnite palaeotemperatures compared to coeval brachiopod-based temperature estimates, when using the same $\delta^{18} \mathrm{O}$ vs temperature relationship for both taxa and assuming a constant oxygen isotope composition for the seawater ${ }^{1,3,46,47}$. To reconcile this discrepancy, it was proposed that belemnites migrated to colder waters ${ }^{47,48}$. However, based on the most current assessment of belemnite palaeobiology 49 , both long-distance and vertical migration to significantly colder waters is unlikely for these animals. Belemnites presumably lived in the upper $200 \mathrm{~m}$ of the water column and were mostly restricted to continental shelves. Our results thus support that the apparent warm temperature estimates derived from brachiopod $\delta^{18} \mathrm{O}$ reflect the kinetic bias in their isotopic compositions ${ }^{12}$.

We have demonstrated that the dual clumped isotope method, i.e., the simultaneous measurement of carbonate $\Delta_{47}$ and $\Delta_{48}$ values in a single phase, makes it possible to identify carbonates that did not precipitate in thermodynamic equilibrium from their parent water. The comparison of the measured isotopic compositions with theoretical predictions enabled us to pinpoint the dominant kinetic processes responsible for the isotopic disequilibrium and to reconstruct carbonate formation temperatures accurately. Our results highlight the potential that dual clumped isotope thermometry holds for accurate palaeoclimate reconstructions and the identification of the kinetic fractionation processes dominant in carbonate (bio)mineralisation.

\footnotetext{
Methods

Samples. Devils Hole vein calcite: A Holocene vein calcite (DHC2-8) that precipitated 4.5-16.9 ka before present, was collected from the Devils Hole cave \#2 in Nevada, USA (36.427138 N, 116.291172 W). It is postulated that DHC2-8 precipitated at extremely slow rates, i.e., $0.1-0.8 \mu \mathrm{m}_{\text {year }}{ }^{-1}$, at a constant temperature of $33.7( \pm 0.8)^{\circ} \mathrm{C}^{30}$. For this study, we prepared a ca $0.5 \times 0.5 \times 1.5 \mathrm{~cm}$ slab of calcite. First, we abraded the surface ca $0.5 \mathrm{~mm}$ of the slab with a slow-speed hand-held drill to remove impurities. Then, the slab was cleaned in de-ionised water in an ultrasonic bath for $5 \mathrm{~min}$ and dried in a vacuum oven at $30^{\circ} \mathrm{C}$ before it was crushed and homogenised using an agate mortar and pestle. Material from the same vein was analysed for clumped isotopes in other studies ${ }^{5,32}$.

Cryogenic cave carbonate: A coarsely crystalline cryogenic cave calcite (MSK 2b) was obtained from Mitterschneidkar Eishöhle in the Austrian Alps $(47.1165 \mathrm{~N}, 11.7407 \mathrm{E})$. The cave opens at $2258 \mathrm{~m}$ above sea level and contained perennial ice in the near-entrance part until 2007. Today the cave is ice-free, and the mean annual air temperature in the interior of the cave is $0.23^{\circ} \mathrm{C}^{33}$. Coarsely crystalline cryogenic cave carbonates generally precipitate slowly and very close to $0{ }^{\circ} \mathrm{C}$, otherwise powder-like fine-crystalline cryogenic cave carbonates form ${ }^{50}$. Cryogenic cave carbonates occur in several places in the inner part of the cave, and U-Th dating of these carbonates suggests the presence of perennial ice up to about 2600 years before present ${ }^{33}$. The sample crystals were crushed and homogenised using an agate mortar and pestle and were subsequently dried in a vacuum oven at $30^{\circ} \mathrm{C}$ before isotope analysis. Additional information on the potential equilibrium nature of this sample is found in Supplementary Fig. 1.
}

Cave pool carbonate: A 3.5-cm thick subaqueous calcite sample (Obi $87-\mathrm{i}$ ) was collected in 2008 from a perennial pool (Silbersee) in Rasslsystem cave, which is part of the Obir Caves (46.5102 N, 14.5480 E), a series of karst caves in the Southern Alps of Austria, located at approximately $1100 \mathrm{~m}$ above sea level. The Obir Caves are hypogene in $\operatorname{origin}^{51}$, i.e., they were not connected to the surface and hence had a very stable microclimate until discovered during mining activities in the 1870s. The Silbersee pool, located in the inner part of Rasslsystem cave, has a surface area of $7 \times 4 \mathrm{~m}$ and is on average ca $1 \mathrm{~m}$ deep. The pool water temperature between 1998 and 2002 was $5.4( \pm 0.1)^{\circ} \mathrm{C}$, closely corresponding to the long-term mean annual air temperature outside the cave at this elevation ${ }^{52}$. The sample analysed in this study is a $4 \mathrm{~mm}$ wide subsample retrieved from $2.7 \mathrm{~cm}$ above the base of Obi 87, and is estimated to have formed at about 1500 years before present based on the U-Th dating of a lower layer in Obi 87 (a layer estimated to have formed about 3800 years before present at $1.5 \mathrm{~cm}$ above the base of Obi 87) and assuming a constant calcite growth rate of $5.3 \mu \mathrm{m} \mathrm{year}^{-1}$ (unpublished data, C Spötl). Although the water temperature about 1500 years before present is not precisely known, it likely corresponded to the mean annual air temperature outside the cave at that time in a similar way as the modern pool temperature does. Various temperature proxy data for the Alps suggest that the mean annual air temperature fluctuated by up to $\pm 1.5^{\circ} \mathrm{C}$ in the last two millennia before the industrial revolution ${ }^{53}$. Considering the $\mathrm{ca} 1.5^{\circ} \mathrm{C}$ warming in the Alps during the past century, we estimate the water temperature of Silbersee pool from which Obi 87-i precipitated ca 1500 years ago to be $4.0( \pm 1.5)^{\circ} \mathrm{C}$. Experiments demonstrated that subaqueous pool carbonates can precipitate in oxygen isotope equilibrium with water ${ }^{54}$. Prior to isotope analyses, Obi 87-i was cleaned in de-ionised water in an ultrasonic bath, crushed and homogenised using an agate mortar and pestle, and dried in a vacuum oven at $30^{\circ} \mathrm{C}$.

Synthetic speleothem carbonate: A calcite sample (MHD1) was precipitated in a laboratory, under cave-like conditions ${ }^{55}$. Solutions super-saturated relative to calcite were pumped to flow down an inclined, sandblasted glass plate in a thin solution film ( $0.1 \mathrm{~mm}$ in thickness), precipitating $\mathrm{CaCO}_{3}$ along the flow path. The experiments were performed in an enclosed space, which allowed control of all surrounding conditions, such as $p \mathrm{CO}_{2}$, temperature, and relative humidity. Specifically, sample MHD1 was precipitated at $30.7( \pm 0.3)^{\circ} \mathrm{C}$, with an atmospheric $p \mathrm{CO}_{2}$ of $1007( \pm 47) \mathrm{ppm}$ and a relative humidity of $97.5( \pm 1.2) \%$. The average $\delta^{13} \mathrm{C}$ and $\delta^{18} \mathrm{O}$ values of the atmospheric $\mathrm{CO}_{2}$ were $-44.7( \pm 0.8) \%$ and $-10.6( \pm 0.6) \%$ VPDB, respectively. The experimental solution was prepared by dissolving $5 \mathrm{mmol}$ $\mathrm{CaCO}_{3}$ powder in high-purity water while bubbling tank $\mathrm{CO}_{2}$ through the water column. After the complete dissolution of $\mathrm{CaCO}_{3}$ powder, i.e., when there were no visible particles in the solution, the solution was stored for five days at the experimental temperature to obtain isotopic equilibrium among all dissolved inorganic carbon species. This resulted in an initial solution composition of $\mathrm{pH}=$ $6.34,[\mathrm{DIC}]=18.19 \mathrm{mM}, \delta^{13} \mathrm{C}_{\mathrm{HCO} 3-} \approx-31.9( \pm 1.3) \%$, and $\delta^{18} \mathrm{O}_{\mathrm{HCO}-} \approx-8.69$ $( \pm 0.11) \%$ VPDB. After being exposed to lower $p \mathrm{CO}_{2}$ in the climate box, it took ca $18 \mathrm{~s}$ for the solution to reach chemical equilibrium with the atmospheric $\mathrm{CO}_{2}$, which increased the solution $\mathrm{pH}$ and led to super-saturation with respect to calcite. The calcite sample was scratched off the glass plate after the experiment was completed and corresponded to the first $5 \mathrm{~cm}$ of flow, i.e., the first $24 \mathrm{~s}$ of $\mathrm{CaCO}_{3}$ precipitation.

Stalagmite: A calcite sample (SPA121-02) was retrieved from a stalagmite in Spannagel Cave in the Austrian Alps (47.0803 N, 11.6717 E), an extensive cave system with the main entrance at $2523 \mathrm{~m}$ above sea level. SPA121-02 is a $4-\mathrm{mm}$ thin layer within SPA121, a stalagmite that records a long growth history from about 240 to $76 \mathrm{ka}$. SPA121-02 was formed at about $225 \mathrm{ka}$ during Marine Isotope Stage (MIS) 7.4 when this high-alpine cave was buried beneath a warm-based glacier preventing the cave from freezing ${ }^{56}$. The growth of this stalagmite during MIS 7 likely occurred at constant temperatures around freezing point, i.e., $0( \pm 2)^{\circ} \mathrm{C}$ The relatively high $\delta^{13} \mathrm{C}$ values of SPA121-02 (about 7\% VPDB, Supplementary Table 1) was attributed to the disequilibrium isotope effects during peak cold times ${ }^{56}$. A $3 \times 6 \times 4 \mathrm{~mm}$ large piece was cut out from the axial part of the stalagmite SPA121 using a diamond-coated band saw. The piece was then cleaned in an ultrasonic bath in de-ionised water, dried, and crushed and homogenised with an agate mortar and pestle before isotope analysis.

Cold-water coral: A scleractinian, azooxanthellate coral Desmophyllum pertusum (formerly known as Lophelia pertusa) (JR) was collected alive at Traenadjupet, Norwegian Sea $(66.973333 \mathrm{~N}, 11.108833 \mathrm{E})$ at a water depth of $300 \mathrm{~m}$ during cruise POS325-356/1. The annual mean seawater temperature at the collection location is $7.2( \pm 1.0)^{\circ} \mathrm{C}^{57}$. With a hand-held drill, a corallite was cut from the axis of the colony, and the septa were removed, i.e., only the theca walls were sampled. The sample was cleaned in an ultrasonic bath using de-ionised water and dried in a vacuum oven at $30^{\circ} \mathrm{C}$ before being crushed and homogenised using an agate mortar and pestle.

Warm-water coral: A scleractinian, zooxanthellate coral Porites lutea (PC1_2005) was collected at the Rashdoo Atoll, Maldives (4.293776 N, 72.977115 E) at a water depth of ca $1 \mathrm{~m}$. For isotope analysis, a ca $0.5 \mathrm{~cm}$ thick section was cut from the coral core. Based on sclerochronological analysis, this section corresponded to the growth in the year 2005 when the annual mean temperature at this location was $29.3( \pm 1.0){ }^{\circ} \mathrm{C}^{58}$. The mean annual extension rate of the coral is ca $10 \mathrm{~mm} \mathrm{year}^{-1}$. To remove material that may have been thermally altered when the section was initially cut from the colony, the surface $0.5 \mathrm{~mm}$ was scraped away. Then, the section was cleaned in an ultrasonic bath using de-ionised water and 
dried in a vacuum oven at $30^{\circ} \mathrm{C}$ before being crushed and homogenised using an agate mortar and pestle.

Modern brachiopod shell: A terebratulid brachiopod Magellania venosa (Mv143-b) was collected from Punta Gruesa, Chile (42.409833 S, 72.424333 W) from $20 \mathrm{~m}$ below sea level. The annual mean temperature at the collection location is $11.4( \pm 1.7){ }^{\circ} \mathrm{C}^{12}$. Magellania venosa is one of the fastest-growing modern brachiopods, with growth rates ranging from $3.8 \mathrm{~mm} \mathrm{year}^{-1}$ (adult) to $17.3 \mathrm{~mm}$ year $^{-1}$ (juvenile) ${ }^{59}$. For this study, we sampled a ca $2 \times 3 \mathrm{~cm}$ area in the middle part of the ventral valve. First, we abraded the primary layer of the shell using a slowspeed hand-held drill and a diamond drill bit, cleaned the shell in an ultrasonic bath with de-ionised water, dried it in a vacuum oven at $30^{\circ} \mathrm{C}$, and finally homogenised the material using an agate mortar and pestle. The anterior part of the same specimen showed the largest offset from equilibrium in $\Delta_{47}$ values in a previous study ${ }^{12}$.

Cretaceous belemnite: A belemnite Belemnopsis sp. (66-4.65) was retrieved from DSDP Site 511 at the Falkland Plateau (51.004667 S, 46.971667 W). The investigated rostrum solidum shows excellent preservation based on cathodoluminescence, and trace element analyses ${ }^{44,60}$. Burial temperatures remained below $100^{\circ} \mathrm{C}$ for this core, which makes the solid-state alteration of the clumped isotope composition of this sample unlikely ${ }^{61,62}$. The same sample in this study was analysed for its $\Delta_{47}$ values, together with other belemnites, to reconstruct Early Cretaceous southern high latitude palaeotemperatures ${ }^{44}$.

Mass spectrometry. We performed the $\mathrm{CO}_{2}$ clumped isotope analyses of sample carbonates on a Thermo Scientific 253 Plus gas source isotope ratio mass spectrometer during April 2019-March 2020, in three measurement sessions (April-August 2019, September-December 2019, and January-March 2020), following the method of Fiebig et al. ${ }^{25}$. Samples were measured in 5-10 replicates. Each replicate analysis consists of 13 acquisitions (10 cycles of reference and samples comparisons in each acquisition and $20 \mathrm{~s}$ integration time during each cycle). The raw clumped isotope values (indicated by subscript "raw" on the $\Delta$ symbol) were calculated using the [Brand]/IUPAC isotopic parameters ${ }^{29,63}$.

Data correction for the reference carbonates. In order to assign the long-term $\Delta_{47}$ (CDES90) and $\Delta_{48}$ (CDES90) values of the ETH 1, ETH 2, and ETH 3 carbonate reference materials finally used for sample correction (Table 1 , see the next section), we followed the correction approach outlined by Fiebig et al. ${ }^{25}$. using equilibrated gases only (subscript "CDES90" on the $\Delta$ symbol indicates that the $\Delta_{47}$ and $\Delta_{48}$ values of these carbonate reference materials are reported on the Carbon Dioxide Equilibrium Scale at a reaction temperature of $90^{\circ} \mathrm{C}$ ). A total of 36 aliquots of $\mathrm{CO}_{2}$ gases equilibrated at $25^{\circ} \mathrm{C}$ and 54 aliquots equilibrated at $1000{ }^{\circ} \mathrm{C}$ were considered for the April-August 2019 period (Supplementary Data 1). Data correction for the reference carbonates consisted of two steps: correction for nonlinearity followed by correction for scale compression ${ }^{25,64,65}$. These two steps are detailed below.

Correction for non-linearity: Within errors, the two sets of equilibrium gases, equilibrated either at $1000^{\circ} \mathrm{C}$ or $25^{\circ} \mathrm{C}$, had identical slopes in $\Delta_{47}$ (raw) vs $\delta_{47}$ (Supplementary Fig. 3a) and $\Delta_{48}$ (raw) vs $\delta_{48}$ (Supplementary Fig. 3b) spaces, respectively, when the negative $\mathrm{m} / z$ 47.5 intensity is directly subtracted from measured $m / z$ 47-49 intensities (scaling factor of -1 , see below and in Fiebig et al. ${ }^{25}$ ). We, therefore, considered the slopes displayed by the merged data sets for the correction of non-linearity. In $\Delta_{47}$ (raw) vs $\delta_{47}$ space, the equilibrium gases showed a flat line such that non-linearity correction needs not be applied. In $\Delta_{48}$ (raw) vs $\delta_{48}$ space, the slope displayed by the merged data set was $-0.0040( \pm 0.0002)$.

Correction for scale compression: The intercepts for the $1000^{\circ} \mathrm{C}$ and the $25^{\circ} \mathrm{C}$ gases displayed in $\Delta_{47 \text { (raw) }}$ vs $\delta_{47}$ and $\Delta_{48}$ (raw) vs $\delta_{48}$ spaces were compared to the corresponding theoretical values ${ }^{66}$ to constrain empirical transfer functions (Supplementary Data 1).

Finally, we combined the $\Delta_{47}$ (CDEs9o and $\Delta_{48}$ (CDEs9o) values of ETH 1, ETH 2 , and ETH 3 determined during the April-August 2019 period (Supplementary Data 1) with those reported in Fiebig et al. ${ }^{25}$ to calculate the long-term values listed in Table 1 (Supplementary Fig. 4). Shapiro-Wilks tests show that the combined $\Delta_{47 \text { (CDES90) }}$ and $\Delta_{48}$ (CDES90) data set of the carbonate reference materials have a normal distribution with $W$-values $>0.95$ and $p$-values $>>0.05$.

Data correction for the carbonate samples. Unlike the method described in Fiebig et al. ${ }^{25}$, we did not make use of equilibrated gases to correct the samples but used our long-term $\Delta_{47}$ (CDES90) and $\Delta_{48}$ (CDES90) values obtained for ETH 1, ETH 2, and ETH 3 instead (Supplementary Data 2-4). This purely carbonate-based correction approach follows the principle of identical treatment of sample and reference materials and allows identification of subtle temporal drifts in the acid reaction environment and correction for them ${ }^{67-69}$. Correction of the sample data consisted of three steps: correction for non-linearity followed by correction for scale compression, and finally correction for variations in the reaction environment. These three steps are detailed below.

Correction for non-linearity: The negative background causing the nonlinearities in $\Delta_{47 \text { (raw) }}$ vs $\delta_{47}, \Delta_{48 \text { (raw) }}$ vs $\delta_{48}$, and $\Delta_{49 \text { (raw) }}$ vs $\delta_{49}$ spaces was corrected using Easotope ${ }^{70}$ by subtracting the intensities measured on the $\mathrm{m} / z 47.5$ cup from the intensities measured on the $m / z 47-49$ cups, after multiplying the former by respective scaling factors. These scaling factors were determined empirically and enable one to calculate accurate negative backgrounds below $\mathrm{m} / \mathrm{z}$ $47, \mathrm{~m} / z 48$, and $\mathrm{m} / \mathrm{z} 49$ from the measured $\mathrm{m} / \mathrm{z} 47.5$ intensity. For the three periods of sample analyses, i.e., April-August 2019, September-December 2019, and January-March 2020, we determined the scaling factors in a way that no residual slopes remained between the respective measured values of the frequently analysed ETH 1 and ETH 2 standards in the corresponding $\Delta$ vs $\delta$ spaces (Supplementary Figs. 5-7). The uniformity of the measured long-term $\Delta_{47}$ (CDES90) and $\Delta_{48}$ (CDES90) values of ETH 1 and ETH 2, also supported by experimental data ${ }^{71}$, allowed us to assume that they have identical $\Delta_{47}$ and $\Delta_{48}$ values (Table 1). Consequently, for the April-August 2019 period of sample analyses, scaling factors of $-0.988,-0.906$, and -0.648 , respectively, were applied to correct $\mathrm{m} / z 47, \mathrm{~m} / z 48$, and $\mathrm{m} / z 49$ intensities based on the monitored $m / z 47.5$ intensity. For the September-December 2019 period, the corresponding scaling factors were $-1.003,-0.938$, and -0.581 , respectively. For the January-March 2020 period, factors of $-1.010,-0.92326$, and -0.555 , respectively, were applied.

Correction for scale compression: According to the principles outlined above, we used our long-term $\Delta_{47}$ (CDES90) and $\Delta_{48}$ (CDES90) values of ETH 1, ETH 2, and ETH 3 (Table 1) to project the non-linearity corrected, raw clumped isotope values of the carbonate samples to the CDES. We determined empirical transfer functions based on a comparison of our long-term mean $\Delta_{47}$ (CDES90) and $\Delta_{48}$ (CDES90) values of ETH 1, ETH 2, and ETH 3 (Table 1) with their corresponding, non-linearity corrected $\Delta_{47}$ (raw) and $\Delta_{48}$ (raw) averages over the three periods of sample analysis (Supplementary Figs. 5a-b, 6a-b, 7a-b). The application of these transfer functions to non-linearity corrected sample $\Delta_{47}$ (raw) and $\Delta_{48}$ (raw) values yields the $\Delta_{47}$ (CDES90,uc) and $\Delta_{48}$ (CDES90,uc) values of the samples (Supplementary Data 2-4).

Correction for subtle long-term variations in the acid reaction environment: When residuals between the accepted long-term and the measured $\Delta$ (CDES90,uc) for all ETH 1, ETH 2, and ETH 3 replicate analyses are plotted against time, small but systematic temporal variations become detectable. For $\Delta_{47}$ (CDES90,uc), these residuals are on the order of $\leq 0.010 \%$ (Supplementary Figs. $8 \mathrm{a}, 9 \mathrm{a}, 10 \mathrm{a}$ ), and for $\Delta_{48}$ (CDES90,uc) they are on the order of $\leq 0.030 \%$ (Supplementary Figs. 8b, 9b, 10b). We determined a residual vs measurement time function (Supplementary Data 2-4) and used it to further correct the $\Delta_{47}$ (CDES90,uc) and $\Delta_{48}$ (CDES90,uc) values in order to obtain the final clumped isotope compositions of the investigated carbonate samples (Table 2).

We used the non-linearity corrected $\Delta_{49}$ (raw) values of the carbonate-derived $\mathrm{CO}_{2}$ and the presumably uncontaminated equilibrated $\mathrm{CO}_{2}$ gases to check for potential contamination in the analyte. All $\Delta_{49}$ (raw) values of the carbonates fall within the range of the $\Delta_{49}$ (raw) values of the equilibrated gases, indicating no contamination of the investigated solids (Supplementary Figs. 11a-b, 12a-b, 13a-b). In addition, the lack of correlation between $\Delta_{48}$ (raw) and $\Delta_{49}$ (raw) of the measured analytes further argues that there is no contamination on $\Delta_{49}$ that would influence $\Delta_{48}$ (Supplementary Figs. 11c, 12c, 13c). All measured values can be found in Supplementary Data $1-4$

Acid fractionation factors. To be able to compare the experimentally measured clumped isotope compositions of a carbonate, i.e., the $\Delta_{47}$ (CDES90) and $\Delta_{48}$ (CDES90) values of the $\mathrm{CO}_{2}$ gas derived from the phosphoric acid digestion of that carbonate, with its theoretically predicted composition, i.e., the $\Delta_{63}$ and $\Delta_{64}$ values of the carbonate, we determined ${ }^{25}$ the clumped isotope fractionation factors associated with the $90^{\circ} \mathrm{C}$ acid fractionation during our analysis. These are based on the longterm $\Delta_{47}$ (CDES90) and $\Delta_{48}$ (CDES90) values of ETH 1 and ETH 2 standards which were both potentially equilibrated at $600^{\circ} \mathrm{C}^{68}$. The theoretically predicted calcite $\Delta_{63}$ and $\Delta_{64}$ values at $600{ }^{\circ} \mathrm{C}$ are $0.018 \%$ and $0.002 \%{ }^{28}$, respectively. These, combined with our experimentally measured $\Delta_{47}$ (CDES90) values of 0.212 $( \pm 0.002) \% 0$ and $\Delta_{48}$ (CDES90) of $0.140( \pm 0.005) \%$, yield acid fractionation factors of $0.194( \pm 0.002) \%$ for $\Delta_{63}-\Delta_{47}$ and $0.138( \pm 0.005) \%$ for $\Delta_{64}-\Delta_{48}$.

Numerical modelling. We used numerical models to simulate the evolution of the isotopic composition of the DIC during (1) $\mathrm{CO}_{2}$ absorption, i.e., the key process involved in coral calcification ${ }^{26}$, and (2) the laboratory carbonate precipitation of the synthetic speleothem ${ }^{27}$ (Supplementary Data 5).

(1) $\mathrm{CO}_{2}$ absorption simulations were constructed using the IsoDIC model to mimic the internal calcification environment of scleractinian corals ${ }^{26}$. Specifically, the modelled calcification environment consisted of an aqueous solution ([DIC] $=$ $2 \mathrm{mM}, \delta^{13} \mathrm{C}_{\mathrm{DIC}}=0$, and $\mathrm{pH}=8.8$ for cold-water corals and $\mathrm{pH}=8.5$ for warmwater corals), which was exposed to a $\mathrm{CO}_{2}$-containing atmosphere $\left(p \mathrm{CO}_{2}=1100\right.$ $\mathrm{ppm}^{72}$ and $\delta^{13} \mathrm{C}_{\mathrm{CO} 2}=-15 \%{ }^{73}$ ). The temperature of the modelled calcification environment corresponded to the mean growth temperatures of the cold- and warm-water corals, i.e., $7.2^{\circ} \mathrm{C}$ and $28.9^{\circ} \mathrm{C}$, respectively. The catalytic enhancement of the inter-conversion between $\mathrm{CO}_{2}$ (aq) and $\mathrm{HCO}_{3}{ }^{-}$by carbonic anhydrase during coral calcification is simulated by increasing the rate constants of $\mathrm{CO}_{2}$ (aq) (de)hydration reactions ${ }^{26}$. The initial oxygen and clumped isotope compositions of both the DIC and air $\mathrm{CO}_{2}$ were assumed to be in isotopic equilibrium with the water $\left(\delta^{18} \mathrm{O}_{\mathrm{H} 2 \mathrm{O}}=0 \mathrm{VSMOW}\right)$ at the above described temperatures.

(2) To model the isotopic composition of the synthetic speleothem, simulations were constructed using the IsoCave model ${ }^{27}$, based on the conditions of the laboratory experiment ${ }^{55}\left(T=30.7^{\circ} \mathrm{C}, p \mathrm{CO}_{2}=1007 \mathrm{ppm}\right.$, water film thickness of $100 \mu \mathrm{m}, \delta^{13} \mathrm{C}_{\mathrm{CO} 2}=-44.7 \%$, $\delta^{18} \mathrm{O}_{\mathrm{CO} 2}=-10.6 \%$ VPDB, $\delta^{13} \mathrm{C}_{\mathrm{CaCO} 3}=-6 \%$, 
$\delta^{18} \mathrm{O}_{\mathrm{H} 2 \mathrm{O}}=-9 \%$ VSMOW, see above as well) and yielded an initial solution composition of $\mathrm{pH}=6.3$, $[\mathrm{DIC}]=18.1 \mathrm{mM},\left[\mathrm{Ca}^{2+}\right]=4.9 \mathrm{mM}, \delta^{13} \mathrm{C}_{\mathrm{HCO} 3-}=$ $-31.2 \%$, and $\delta^{18} \mathrm{O}_{\mathrm{HCO}-}=-9.0 \%$ VPDB, which are close to the experimentally determined values $\left(\mathrm{pH}=6.34\right.$, $[\mathrm{DIC}]=18.2 \mathrm{mM},\left[\mathrm{Ca}^{2+}\right]=5 \mathrm{mM}, \delta^{13} \mathrm{C}_{\mathrm{HCO} 3-} \approx$ $-31.9( \pm 1.3) \%$, and $\delta^{18} \mathrm{O}_{\mathrm{HCO} 3} \approx-8.69( \pm 0.11) \%$ VPDB, see above $)$.

\section{Data availability}

The analytical and model data supporting the findings of this study are available within the article, its Supplementary Information, and Supplementary Data files. All data files are additionally deposited at: [https://doi.org/10.5281/zenodo.3784963]

\section{Code availability}

The figures were generated using code written in R, available at: [https://doi.org/10.5281/ zenodo.3784963]

Received: 22 November 2019; Accepted: 26 June 2020;

Published online: 10 August 2020

\section{References}

1. Urey, H. C., Lowenstam, H. A., Epstein, S. \& Mckinney, C. R. Measurement of paleotemperatures and temperatures of the Upper Cretaceous of England, Denmark, and the southeastern United States. Geol. Soc. Am. Bull. 62, 399-416 (1951).

2. Hendy, C. H. The isotopic geochemistry of speleothems-I. The calculation of the effects of different modes of formation on the isotopic composition of speleothems and their applicability as palaeoclimatic indicators. Geochim. Cosmochim. Acta 35, 821-824 (1971).

3. Veizer, J. \& Prokoph, A. Temperatures and oxygen isotopic composition of Phanerozoic oceans. Earth-Sci. Rev. 146, 92-104 (2015).

4. Eiler, J. M. Paleoclimate reconstruction using carbonate clumped isotope thermometry. Quat. Sci. Rev. 30, 3575-3588 (2011).

5. Daëron, M. et al. Most Earth-surface calcites precipitate out of isotopic equilibrium. Nat. Commun. 10, 429 (2019).

6. Affek, H. P., Bar-Matthews, M., Ayalon, A., Matthews, A. \& Eiler, J. M. Glacial/interglacial temperature variations in Soreq cave speleothems as recorded by 'clumped isotope' thermometry. Geochim. Cosmochim. Acta 72, 5351-5360 (2008).

7. Daëron, M. et al. ${ }^{13} \mathrm{C}^{18} \mathrm{O}$ clumping in speleothems: observations from natural caves and precipitation experiments. Geochim. Cosmochim. Acta 75, 3303-3317 (2011).

8. McDermott, F., Atkinson, T. C., Fairchild, I. J., Baldini, L. M. \& Mattey, D. P. A first evaluation of the spatial gradients in $\delta^{18} \mathrm{O}$ recorded by European Holocene speleothems. Glob. Planet. Change 79, 275-287 (2011).

9. Wainer, K. et al. Speleothem record of the last $180 \mathrm{ka}$ in Villars cave (SW France): Investigation of a large $\delta^{18} \mathrm{O}$ shift between MIS6 and MIS5. Quat. Sci. Rev. 30, 130-146 (2011).

10. Lowenstam, H. A. Mineralogy, $\mathrm{O}^{18} / \mathrm{O}^{16}$ ratios, and strontium and magnesium contents of recent and fossil brachiopods and their bearing on the history of the oceans. Journ. Geol. 69, 241-260 (1961).

11. Carpenter, S. J. \& Lohmann, K. C. $\delta^{18} \mathrm{O}$ and $\delta^{13} \mathrm{C}$ values of modern brachiopod shells. Geochim. Cosmochim. Acta 59, 3749-3764 (1995).

12. Bajnai, D. et al. Assessing kinetic fractionation in brachiopod calcite using clumped isotopes. Sci. Rep. 8, 533 (2018).

13. Rollion-Bard, C. et al. Assessing the biomineralization processes in the shell layers of modern brachiopods from oxygen isotopic composition and elemental ratios: implications for their use as paleoenvironmental proxies. Chem. Geol. 524, 49-66 (2019).

14. McConnaughey, T. ${ }^{13} \mathrm{C}$ and ${ }^{18} \mathrm{O}$ isotopic disequilibrium in biological carbonates: I. Patterns. Geochim. Cosmochim. Acta 53, 151-162 (1989).

15. Thiagarajan, N., Adkins, J. \& Eiler, J. Carbonate clumped isotope thermometry of deep-sea corals and implications for vital effects. Geochim. Cosmochim. Acta 75, 4416-4425 (2011).

16. Saenger, C. et al. Carbonate clumped isotope variability in shallow water corals: temperature dependence and growth-related vital effects. Geochim. Cosmochim. Acta 99, 224-242 (2012).

17. Kimball, J., Eagle, R. \& Dunbar, R. Carbonate "clumped" isotope signatures in aragonitic scleractinian and calcitic gorgonian deep-sea corals. Biogeosciences 13, 6487-6505 (2016).

18. Spooner, P. T. et al. Clumped isotope composition of cold-water corals: a role for vital effects? Geochim. Cosmochim. Acta 179, 123-141 (2016)

19. Cohen, A. L. \& McConnaughey, T. A. Geochemical perspectives on coral mineralization. Rev. Mineral. Geochem. 54, 151-187 (2003).

20. Rollion-Bard, C., Blamart, D., Cuif, J.-P. \& Dauphin, Y. In situ measurements of oxygen isotopic composition in deep-sea coral, Lophelia pertusa: re- examination of the current geochemical models of biomineralization. Geochim. Cosmochim. Acta 74, 1338-1349 (2010).

21. Kluge, T. \& Affek, H. P. Quantifying kinetic fractionation in Bunker Cave speleothems using $\Delta_{47}$. Quat. Sci. Rev. 49, 82-94 (2012).

22. Smith, J. E., Schwarcz, H. P., Risk, M. J., McConnaughey, T. A. \& Keller, N. Paleotemperatures from deep-sea corals: overcoming 'vital effects'. Palaios $\mathbf{1 5}$ 25-32 (2000).

23. Dennis, K. J., Cochran, J. K., Landman, N. H. \& Schrag, D. P. The climate of the Late Cretaceous: new insights from the application of the carbonate clumped isotope thermometer to Western Interior Seaway macrofossil. Earth Planet. Sci. Lett. 362, 51-65 (2013).

24. Brand, U. et al. Brachiopod-based oxygen-isotope thermometer: update and review. Riv. It. Paleontol. Strat. 125, 775-787 (2019).

25. Fiebig, J. et al. Combined high-precision $\Delta_{48}$ and $\Delta_{47}$ analysis of carbonates. Chem. Geol. 522, 186-191 (2019).

26. Guo, W. Kinetic clumped isotope fractionation in the DIC- $\mathrm{H}_{2} \mathrm{O}-\mathrm{CO}_{2}$ system: patterns, controls, and implications. Geochim. Cosmochim. Acta 268, 230-257 (2020).

27. Guo, W. \& Zhou, C. Patterns and controls of disequilibrium isotope effects in speleothems: insights from an isotope-enabled diffusion-reaction model and implications for quantitative thermometry. Geochim. Cosmochim. Acta 267, 196-226 (2019).

28. Hill, P. S., Tripati, A. K. \& Schauble, E. A. Theoretical constraints on the effects of $\mathrm{pH}$, salinity, and temperature on clumped isotope signatures of dissolved inorganic carbon species and precipitating carbonate minerals. Geochim. Cosmochim. Acta 125, 610-652 (2014).

29. Petersen, S. V. et al. Effects of improved ${ }^{17} \mathrm{O}$ correction on interlaboratory agreement in clumped isotope calibrations, estimates of mineral-specific offsets, and temperature dependence of acid digestion fractionation. Geochem. Geophys. Geosyst. 20, 3495-3519 (2019).

30. Coplen, T. B. Calibration of the calcite-water oxygen-isotope geothermometer at Devils Hole, Nevada, a natural laboratory. Geochim. Cosmochim. Acta 71 3948-3957 (2007)

31. Kluge, T., Affek, H. P., Dublyansky, Y. \& Spötl, C. Devils Hole paleotemperatures and implications for oxygen isotope equilibrium fractionation. Earth Planet. Sci. Lett. 400, 251-260 (2014).

32. Tripati, A. K. et al. Beyond temperature: clumped isotope signatures in dissolved inorganic carbon species and the influence of solution chemistry on carbonate mineral composition. Geochim. Cosmochim. Acta 166, 344-371 (2015).

33. Spötl, C. \& Cheng, H. Holocene climate change, permafrost and cryogenic carbonate formation: insights from a recently deglaciated, high-elevation cave in the Austrian Alps. Clim 10, 1349-1362 (2014).

34. Kluge, $\mathrm{T}$. et al. Clumped isotope thermometry of cryogenic cave carbonates. Geochim. Cosmochim. Acta 126, 541-554 (2014).

35. Fernandez, A. et al. A reassessment of the precision of carbonate clumped isotope measurements: implications for calibrations and paleoclimate reconstructions. Geochem. Geophys. Geosyst. 18, 4375-4386 (2017).

36. McConnaughey, T. ${ }^{13} \mathrm{C}$ and ${ }^{18} \mathrm{O}$ isotopic disequilibrium in biological carbonates: II. In vitro simulation of kinetic isotope effects. Geochim. Cosmochim. Acta 53, 163-171 (1989).

37. Watson, E. B. A conceptual model for near-surface kinetic controls on the trace-element and stable isotope composition of abiogenic calcite crystals. Geochim. Cosmochim. Acta 68, 1473-1488 (2004).

38. DePaolo, D. J. Surface kinetic model for isotopic and trace element fractionation during precipitation of calcite from aqueous solutions. Geochim. Cosmochim. Acta 75, 1039-1056 (2011).

39. Affek, H. P. \& Zaarur, S. Kinetic isotope effect in $\mathrm{CO}_{2}$ degassing: Insight from clumped and oxygen isotopes in laboratory precipitation experiments. Geochim. Cosmochim. Acta 143, 319-330 (2014).

40. Watkins, J. M. \& Hunt, J. D. A process-based model for non-equilibrium clumped isotope effects in carbonates. Earth Planet. Sci. Lett. 432, 152-165 (2015).

41. Dreybrodt, W. \& Scholz, D. Climatic dependence of stable carbon and oxygen isotope signals recorded in speleothems: from soil water to speleothem calcite. Geochim. Cosmochim. Acta 75, 734-752 (2011).

42. Fairchild, I. J. \& Baker, A. Speleothem Science: From Process to Past Environments. (Wiley-Blackwell, 2012).

43. Kluge, T. et al. Reconstruction of drip-water $\delta^{18} \mathrm{O}$ based on calcite oxygen and clumped isotopes of speleothems from Bunker Cave (Germany). Clim. Past $\mathbf{9}$, 377-391 (2013)

44. Vickers, M. L., Bajnai, D., Price, G. D., Linckens, J. \& Fiebig, J. Southern high latitude warmth during the Jurassic-Cretaceous: new evidence from clumped isotope thermometry. Geology 47, 724-728 (2019).

45. Jenkyns, H. C., Schouten-Huibers, L., Schouten, S. \& Sinninghe Damsté, J. S. Warm Middle Jurassic-Early Cretaceous high-latitude sea-surface temperatures from the Southern Ocean. Clim 8, 215-226 (2012).

46. Voigt, S., Wilmsen, M., Mortimore, R. N. \& Voigt, T. Cenomanian palaeotemperatures derived from the oxygen isotopic composition of 
brachiopods and belemnites: evaluation of Cretaceous palaeotemperature proxies. Int. J. Earth Sci. 92, 285-299 (2003).

47. Alberti, M., Fürsich, F. T. \& Pandey, D. K. The Oxfordian stable isotope record $\left(\delta^{18} \mathrm{O}, \delta^{13} \mathrm{C}\right)$ of belemnites, brachiopods, and oysters from the Kachchh Basin (western India) and its potential for palaeoecologic, palaeoclimatic, and palaeogeographic reconstructions. Palaeogeogr. Palaeoclimatol. Palaeoecol. 344-345, 49-68 (2012).

48. Zakharov, Y. D. et al. Late Barremian-early Aptian climate of the northern middle latitudes: Stable isotope evidence from bivalve and cephalopod molluscs of the Russian Platform. Cretac. Res. 44, 183-201 (2013).

49. Hoffmann, R. \& Stevens, K. The palaeobiology of belemnites - foundation for the interpretation of rostrum geochemistry. Biol. Rev. 95, 94-123 (2020).

50. Žák, K. et al. in Ice Caves (eds Aurel Perşoiu \& Stein-Erik Lauritzen) Ch. 6, 123-162 (Elsevier, 2018).

51. Spötl, C., Plan, L. \& Dublyansky, Y. in Hypogene Karst Regions and Caves of the World Cave and Karst Systems of the World (eds Alexander Klimchouk et al.) Ch. 6, Springer, 113-126 (2017).

52. Spötl, C., Fairchild, I. J. \& Tooth, A. F. Cave air control on dripwater geochemistry, Obir Caves (Austria): implications for speleothem deposition in dynamically ventilated caves. Geochim. Cosmochim. Acta 69, 2451-2468 (2005).

53. Affolter, S. et al. Central Europe temperature constrained by speleothem fluid inclusion water isotopes over the past 14,000 years. Sci. Adv. 5, eaav3809 (2019).

54. Wiedner, E. et al. Investigation of the stable isotope fractionation in speleothems with laboratory experiments. Quat. Int. 187, 15-24 (2008).

55. Hansen, M., Scholz, D., Schöne, B. R. \& Spötl, C. Simulating speleothem growth in the laboratory: determination of the stable isotope fractionation $\left(\delta^{13} \mathrm{C}\right.$ and $\delta^{18} \mathrm{O}$ ) between $\mathrm{H}_{2} \mathrm{O}$, DIC and $\mathrm{CaCO}_{3}$. Chem. Geol. 509, 20-44 (2019).

56. Spötl, C., Scholz, D. \& Mangini, A. A terrestrial U/Th-dated stable isotope record of the Penultimate Interglacial. Earth Planet. Sci. Lett. 276, 283-292 (2008).

57. Raddatz, J. et al. Stable Sr-isotope, $\mathrm{Sr} / \mathrm{Ca}, \mathrm{Mg} / \mathrm{Ca}, \mathrm{Li} / \mathrm{Ca}$ and $\mathrm{Mg} / \mathrm{Li}$ ratios in the scleractinian cold-water coral Lophelia pertusa. Chem. Geol. 352, 143-152 (2013).

58. Storz, D. \& Gischler, E. Coral extension rates in the NW Indian Ocean I: reconstruction of 20th century SST variability and monsoon current strength. Geo-Mar. Lett. 31, 141-154 (2011).

59. Baumgarten, S., Laudien, J., Jantzen, C., Häussermann, V. \& Försterra, G. Population structure, growth and production of a recent brachiopod from the Chilean fjord region. Mar. Eco. 35, 401-413 (2014).

60. Price, G. D. \& Sellwood, B. W. "Warm" palaeotemperatures from high Late Jurassic palaeolatitudes (Falkland Plateau): ecological, environmental or diagenetic controls? Palaeogeogr. Palaeoclimatol. Palaeoecol. 129, 315-327 (1997).

61. Langseth, M. G. \& Ludwig, W. J. A heat flow measurement on the Falkland Plateau. Initial Rep. Deep Sea 71, 299-303 (1983).

62. Passey, B. H. \& Henkes, G. A. Carbonate clumped isotope bond reordering and geospeedometry. Earth Planet. Sci. Lett. 351-352, 223-236 (2012).

63. Brand, W. A., Assonov, S. S. \& Coplen, T. B. Correction for the ${ }^{17} \mathrm{O}$ interference in $\delta\left({ }^{13} \mathrm{C}\right)$ measurements when analyzing $\mathrm{CO}_{2}$ with stable isotope mass spectrometry (IUPAC Technical Report). Pure Appl. Chem. 82, 1719-1733 (2010).

64. Huntington, $\mathrm{K}$. W. et al. Methods and limitations of 'clumped' $\mathrm{CO}_{2}$ isotope $\left(\Delta_{47}\right)$ analysis by gas-source isotope ratio mass spectrometry. J. Mass Spectrom. 44, 1318-1329 (2009).

65. Dennis, K. J., Affek, H. P., Passey, B. H., Schrag, D. P. \& Eiler, J. M. Defining an absolute reference frame for 'clumped' isotope studies of $\mathrm{CO}_{2}$. Geochim. Cosmochim. Acta 75, 7117-7131 (2011).

66. Wang, Z., Schauble, E. A. \& Eiler, J. M. Equilibrium thermodynamics of multiply substituted isotopologues of molecular gases. Geochim. Cosmochim. Acta 68, 4779-4797 (2004).

67. Passey, B. H., Levin, N. E., Cerling, T. E., Brown, F. H. \& Eiler, J. M. Hightemperature environments of human evolution in East Africa based on bond ordering in paleosol carbonates. Proc. Natl Acad. Sci. USA 107, 11245-11249 (2010).

68. Bernasconi, S. M. et al. Reducing uncertainties in carbonate clumped isotope analysis through consistent carbonate-based standardization. Geochem. Geophys. Geosyst. 19, 2895-2914 (2018).
69. Meier-Augenstein, W. \& Schimmelmann, A. A guide for proper utilisation of stable isotope reference materials. Isotopes Environ. Health Stud. 55, 113-128 (2019).

70. John, C. M. \& Bowen, D. Community software for challenging isotope analysis: First applications of 'Easotope' to clumped isotopes. Rap. Commun. Mass Spec. 30, 2285-2300 (2016).

71. Müller, I. A. et al. Clumped isotope fractionation during phosphoric acid digestion of carbonates at $70^{\circ} \mathrm{C}$. Chem. Geol. 449, 1-14 (2017).

72. Cai, W. J. et al. Microelectrode characterization of coral daytime interior $\mathrm{pH}$ and carbonate chemistry. Nat. Commun. 7, 11144 (2016).

73. Swart, P. K. et al. The isotopic composition of respired carbon dioxide in scleractinian corals: Implications for cycling of organic carbon in corals. Geochim. Cosmochim. Acta 69, 1495-1509 (2005).

\section{Acknowledgements}

This work became possible through DFG grant "INST 161/871-1" and the Investment in Science Fund at Woods Hole Oceanographic Institution. The authors would like to thank Sven Hofmann and Manuel Schumann for their assistance in the joint Goethe University - Senckenberg BiK-F Stable Isotope Facility at the Institute of Geosciences, Goethe University Frankfurt. K.M. acknowledges funding through "DFG ME 4955/1-1", E.K. through "DFG MU 2845/6-1", D.S. through "DFG SCHO 1274/8-1" and "DFG SCHO 1274/11-1", and M.H. through "DFG HA 8694/1-1". C.S. acknowledges funding from the University of Innsbruck. A review of the manuscript by David Evans on behalf of the USGS is acknowledged. Any use of trade, firm, or product names is for descriptive purposes only and does not imply endorsement by the US Government.

\section{Author contributions}

D.B., W.G., and J.F. planned the study, interpreted the data, and wrote the manuscript with contributions from all authors. D.B., N.L., K.M., E.K., and J.F. performed the clumped isotope analyses. W.G. conducted the numerical modelling. T.B.C., E.G., M.H., D.H., G.D.P., J.R., D.S., and C.S. collected and provided the samples.

\section{Competing interests}

The authors declare no competing interests.

\section{Additional information}

Supplementary information is available for this paper at https://doi.org/10.1038/s41467020-17501-0.

Correspondence and requests for materials should be addressed to D.B. or J.F.

Peer review information Nature Communications thanks Benjamin Passey and the other, anonymous, reviewer(s) for their contribution to the peer review of this work

Reprints and permission information is available at http://www.nature.com/reprints

Publisher's note Springer Nature remains neutral with regard to jurisdictional claims in published maps and institutional affiliations.

Open Access This article is licensed under a Creative Commons Attribution 4.0 International License, which permits use, sharing, adaptation, distribution and reproduction in any medium or format, as long as you give appropriate credit to the original author(s) and the source, provide a link to the Creative Commons license, and indicate if changes were made. The images or other third party material in this article are included in the article's Creative Commons license, unless indicated otherwise in a credit line to the material. If material is not included in the article's Creative Commons license and your intended use is not permitted by statutory regulation or exceeds the permitted use, you will need to obtain permission directly from the copyright holder. To view a copy of this license, visit http://creativecommons.org/ licenses/by/4.0/.

(C) The Author(s) 2020 